\title{
Den bortträngda skulden och tvånget att tiga
}

En romanförfattares anteckningar om det finländska ödesåret 1918

DEN HÄR ESSÄN BASERAR sig på ett föredrag med rubriken "Suomenruotsalaisuus ja sisällissota" (sv."Finlandssvenskheten och inbördeskriget”) som jag höll i Björneborg, på Helsingfors arbetarinstitut (Helsingin työväenopisto) och i Sammatti under åren 2017 och 2018. I föredraget ville jag sammanfatta mina viktigaste tankar och känslor i förhållande till inbördeskriget, liksom till tiden före och efter kriget. Därför använde jag föredraget som utgångspunkt också för tre andra anföranden som jag lovat hålla i ämnet. Efter hand lade jag till teman och försökte fördjupa och problematisera mitt eget tänkande kring detta ödesår. För så är det. Händelserna år I9ı18, och alla de komplexa frågor om moral, ansvar och skuld som hänger ihop med dem, tvingar oss ännu i dag, mer än hundra år senare, att ifrågasätta våra egna tankar och attityder.

Jag kommer här att behandla inbördeskriget ur ett finlandssvenskt perspektiv. Det betyder inte att jag ser språkfrågan som primär, eller ens särskilt viktig då man granskar detta tragiska år. Som jag ser det hade inbördeskriget sin bakgrund i sociala konflikter och samhällelig orättvisa. Även om språkfrågan var starkt närvarande på vissa områden och orter, och även om den påverkade människors attityder, ofta med tragiska följder, så spelade den inte huvudrollen. Men det är ändå ärligast att jag behandlar ämnet ur detta perspektiv då jag en gång är svenskspråkig. Hur mycket jag än ser mig som en starkt tvåspråkig finländare, ligger frågorna och skälver under ytan. Så som

Den här essän tillägnas minnet av Johannes Salminen och hans gärning. 
denna: har mitt modersmål haft en betydelse för hur jag skildrat inbördeskrigets tid och livsöden i mina romaner Där vi en gång gått (2006) och Hägring 38 (2013)?

Och visst har jag också ett annat motiv till att välja finlandssvenskheten som infallsvinkel. Jag tänker nämligen ta utgångspunkt $\mathrm{i}$ en fördom som jag stött på många gånger under mitt liv. Denna fördom bygger på påståendet att så gott som alla svenskspråkiga medborgare i Finland är ättlingar till feodalsamhällets gamla överklass. Jag, som till minst 90 procent härstammar från österbottniska småbönder, fiskare och även fabriksarbetare, har haft svårt att svälja denna föreställning. Mina förfäder och anmödrar levde under århundraden i mellersta Österbotten, mellan Jakobstad och Karleby, och tillhörde just detta småfolk. Att det i min mammas släkt hittas en fabrikör några generationer tillbaka, och att min pappa sedermera gjorde en social resa, från den fattiga barndomen i Jakobstad till tillvaron som verkställande direktör för ett stort bolag i Helsingfors, förändrar inte kärnan i detta. Och därför har fördomen irriterat mig. Märk väl att det handlar om en seglivad fördom - jag har mött den i Sverige, särskilt i vänsterkretsar, och jag har mött den bland finskspråkiga med mycket varierande bakgrunder. Och det sorgligaste av allt - jag har mött den här fördomen också i finlandssvenskarnas egna kretsar, för bland oss finns också de som vill upprätthålla myten om att vår språkgrupp som helhet utgör en elit $\mathrm{i}$ vårt land.

När man kombinerar denna fördom med vårt inbördeskrig och med hur dessa dystra tider länge omtalades bland folket, så blir bilden tydlig: man föreställde sig att alla finlandssvenskar befann sig på den vita sidan, att de tillhörde den grupp som de röda kallade för "lahtarit", en benämning härledd ur det svenska ordet"slaktare". Det är här jag tar min utgångspunkt. Först kommer jag att gå igenom hur jag behandlat året I 918 i mina romaner. Och jag vet att jag till en början kanske rentav kommer att förstärka myten om att finlandssvenskarna ju alla stod på den vita sidan. Men om bara läsaren orkar läsa vidare, kommer en mångsidigare bild att framträda.

Jag kommer inte att nämna alla källor vid namn, och jag minns ärligt talat inte mera namnen och rubrikerna för somliga av dessa källor. Under en period läste jag enorma mängder böcker, artiklar och brev då jag försökte förstå inbördeskriget för att kunna skriva 
romanerna Vådan av att vara Skrake (2000), Där vi en gång gått och Hägring 38. Men det är en tag sedan dess och en del av mitt handbibliotek finns, som en konsekvens av ett idogt flyttande, nu i lådor uppe på min vind. Låt mig också betona, att även om jag upplever historikerna som mina själsfränder så är romanförfattarens uppgift trots allt en annan än historikerns. Som den amerikanska författaren Siri Hustvedt har formulerat det, skriver romanförfattaren om saker som kunde ha hänt. En historiker skriver om saker som faktiskt har hänt. Det här betyder inte att romanförfattare inte skulle ha ansvar för vad de skriver. Deras ansvar är bara av en annan typ än historikerns. Själv tillämpar jag i alla mina romaner, men kanske allra mest då jag skriver om inbördeskriget och andra politiskt eldfängda ämnen, just denna Hustvedts tanke om plausibilitet. Jag beskriver endast scener och händelser som enligt min uppfattning kunde ha utspelat sig, och som sannolikt också har utspelat sig i någon form.

I min andra roman, Vådan av att vara Skrake, har jag för första gången ett motiv som anknyter till inbördeskriget. Boken handlar om en österbottnisk familj där de manliga familjemedlemmarna under flera generationer försöker göra karriär och bli framgångsrika i Helsingfors, men förgäves. Parallellt med släkten Skrakes historia berättar jag också, om än i modifierad form, om en natt i början av mars I9I8 i den stad som i romanen kallas Tobaksstaden, men som i verkligheten syftar på Jakobstad, den stad där mina föräldrar föddes och växte upp.

Huvudlinjerna i den här berättelsen, som bara utgör en liten del av romanen, är som följer: Vi befinner oss i Jakobstad vintern r9I8. Staden behärskas, liksom hela det övriga Österbotten och norra Finland, av de vita. Enligt många både samtida och senare källor var de röda $\mathrm{i}$ staden rätt så fogliga, inte militanta.

Befälsordningen i staden var oklar denna krigsvinter. Ledare för stadens vita artilleriskola var den sverigesvenska adelsmannen Adolf Hamilton; i staden verkade även skyddskårens överbefälhavare Lauri Malmberg, som senare blev försvarsminister, och därtill ytterligare nästan hundra jägare som stridit vid östfronten i Tyskland.

Natten till den andra mars bestämde sig en grupp berusade vita som samlats i stadshotellets kabinett i Jakobstad för att utöva "ståndrätt” mot sex av stadens röda som hållits i fångenskap. Den tidigare landssekreteraren i Vasa län, en finskspråkig jurist vid namn Johannes 
Jääskeläinen, som anmält sig som frivillig vid de vitas artilleriskola, protesterade. Han menade att rättegången var lagstridig och att de övriga vita aktörerna var berusade. Jääskeläinen, som i yngre år deltagit i socialdemokratisk verksamhet och vid Jyväskylä Lyceum varit klasskamrat med de kända revolutionärerna Edvard Gylling och Otto Wille Kuusinen, ställdes bland de anklagade. Under natten arkebuserades både fångarna och Jäskkeläinen, och deras kroppar lades framför trapporna till arbetarföreningens lokal.

Det här var den första berättelsen från I9I8 som jag omarbetade och gav fiktiv form i en roman. På ett tidstypiskt sätt innehåller den ett otal sociala och psykologiska spänningsfält. Hamilton är sverigesvensk och adlig. De finländska jägarna har nyss återvänt från Tyskland och har sannolikt blivit avtrubbade och förråats vid östfronten. Bland jägarna fanns både svensk- och finskspråkiga; av namnen att döma fanns både svensk- och finskspråkiga även bland de arkebuserade röda, bland dem skådespelaren Martti Suosalos farfarsfar Kalle, tidigare riksdagsledamot för SDP.

När man grubblar på den där natten, på vad som sagts och förmodligen också skrikits, då vaknar frågorna. Vilken betydelse hade till exempel Johannes Jääskeläinens tidigare liv? Dödades han bara för att han ifrågasatte de berusade kamraternas olagliga verksamhet, eller har också språkfrågan kommit till ytan under natten? Då han som ung sökte arbete hade Jääskeläinen flera gånger förbigåtts till förmån för svenskspråkiga sökande och rentav övervägt att emigrera till Nordamerika, men han stannade i Finland för att kämpa för det finska språket. Jag har såpass livlig fantasi att jag under romanskrivandet ryste vid tanken på vad de inblandade möjligen skrikit till varandra under den natten och vilka argument som använts. Jag vill påpeka att man i dag kunde granska Jääskeläinens öde med utgångspunkt i det populära intersektionalitetsperspektivet, och alltså ta fasta på komplexiteten $\mathrm{i}$ den enskilda människans identitet. Vilken av Jäs̈skeläinens identiteter har varit avgörande den där natten: den borgerliga världssynen, den juridiska utbildningen, finskspråkigheten och ungdomens kamp för det finska språket, kopplingen till de kända socialistiska skolkamraterna. Eller ytterligare någon, för oss okänd identitet?

I Vådan av att vara Skrake finns också andra motiv som anknyter till inbördeskriget, även om jag inte går lika djupt i skildringen av 
krigsåret som i vissa av mina senare romaner. Jag beskriver bland annat hur den unga överklassflickan Maggie Enerot spelar Franz Schuberts musik på pianot i sitt hem i Eira i Helsingfors sommaren I9I8, och hon gör det för att slippa känna den kväljande liklukten som bärs över vattnet från fånglägret på Sveaborg, bara en knapp kilometer därifrån.

Låt oss gå till de berättelser som utspelar sig i Helsingfors och i dess närkommuner, och som hör till romanen Där vi en gång gått. När inbördeskriget bryter ut den 27 januari tar de röda makten över nästan hela södra Finland. Men unga män på den vita sidan bildar frikårer i bland annat Kyrkslätt, Sjundeå och Pellinge, och gör sedan motstånd mot det röda väldet. Under dessa första veckor av kriget och långt in i mars begick de röda tiotals och åter tiotals besinningslösa mord på civila, och de morden blir sedan en etablerad och viktig del av de vitas berättelse om de rödas extrema råhet. Det är bland annat med dessa berättelser krigets vita vinnare senare vill motivera och rättfärdiga de summariska avrättningarna av röda, de outhärdliga förhållandena i fånglägren liksom massdöden i svält och sjukdomar.

Jag nämner här bara några av de beryktade mordfall som blev ikoniska och kom att prägla den vita allmänhetens bild av kriget. Bröderna Valter, William och Ivar Thomé mördades då de försökte ansluta sig till frikårerna väster om Helsingfors. ${ }^{1}$ Den unga läkaren Gösta Schybergson mördades på Tölövikens is, efter att de röda tagit honom till fånga och fört bort honom från Kammio sjukhus. Oskar Rosenqvist som var rektor för Svenska handelshögskolan mördades på Jungfrustigen i Helsingfors natten mot den 12 mars.

Dessa gärningar och många andra var motiverade av hat, och de skapade hat bland motståndarna - handlingar som växer ur hat ger alltid upphov till ännu mer hat. Och man kan också föreställa sig att vetskapen om händelserna i Jakobstad natten mot den andra mars

I. Valter och Ivar Thomé var arkitekter och deras förslag hade strax före inbördeskriget vunnit tävlingen som utlysts för Stockmanns nya varuhusbyggnad i Helsingfors. Men Sigurd Frosterus förslag, som kommit på andra plats, var det som sedan förverkligades, kanske just för att bröderna Thomé var döda. 
nått det röda Helsingfors tio dagar senare, och att den vetskapen kan ha eldat på hatet hos de röda som mördade rektor Rosenquist.

Ovannämnda och andra liknande besinningslösa mord på civila har sedan mycket snabbt förvandlats till berättelser om hjältar och offer, och dessa hjälteoffer har blivit legender med vilka den vita sidan sedan velat motivera sin hämnd; med påminnelser om de här gärningarna har man försökt bevisa det oundvikliga och moraliskt rättfärdiga i hämnden. Det onda får sin lön, öga för öga - vår civilisation har genom tiderna haft mängder av talesätt med vilka man har berättigat det hårdaste möjliga straffet.

Jag vill påpeka att trots att vi finländare numera, enligt min uppfattning, kan diskutera I9I8 mer sansat, och bättre än förut respekterar varandras olika åsikter om krigets orsaker och förlopp, så finns det fortfarande smärtpunkter och obalans. En form av obalans finns i att den vita sidans civila offer - med rätta - blir ihågkomna och får namn och ansikten, medan krigets förlorare, de röda offren, fortfarande presenteras som en ansiktslös folkmassa, en anonym grupp. Början av inbördeskriget var en tid av röd terror, men mot slutet av kriget och i efterdyningarna av det byttes rollerna radikalt. Röda som var oskyldiga eller anklagades för mycket lindriga brott blev skjutna eller dog i fångläger, men eftersom de var krigets förlorare, återberättades deras öden inte i form av hjälteberättelser i landets mainstreammedier, på sin höjd berättade man om dem i arbetarpressen eller i viskande samtal under arbetarbefolkningens sammankomster. Deras grymma öden förvandlades inte till nationella berättelser så som berättelserna om de vita civila mordoffren. Därför var det länge svårare att se att också de som dog på den röda sidan - och de var sammanlagt långt över 25000 - var individer med ett eget livsöde, älskade människor som lämnade efter sig sörjande familjemedlemmar och vänner.

De vita frikårerna som bildats genast efter krigsutbrottet avväpnades snabbt både öster och väster om Helsingfors, och fångarna - många av dem unga pojkar, knappt ens fullvuxna - fördes till dåvarande Svenska Reallyceum på Elisabetsgatan i Helsingfors, det nuvarande Sibelius-lukio (sv. Sibelius-gymnasiet). Den här händelsen skildrar jag i fiktiv form i Där vi en gång gått. De vita fångarna i reallyceets byggnad på Elisabetsgatan var upproriska unga män. En del av dem tillhörde överklassen i Helsingfors, andra var söner till godsägare och 
storbönder och de hade på sina hemorter upplevt att deras släkter var viktiga och inflytelserika. I romanen skildrar jag deras känsla av förödmjukelse då de tvingas vara fångar hos de röda i över en månad. Och jag skildrar hur de friges i april, då de tyska trupperna intagit Helsingfors, och hur en del av dem ger sig ut för att hämnas både sin egen förödmjukelse och vinterns mord på deras skol- och studiekamrater - just de mord jag berättade om ovan.

De vitas samtida berättelser, de som skrevs i stundens berusning och då upplevelserna var färska, och som utgavs ännu samma år eller I9I9, avslutas nästan alltid med att de vita vunnit slaget om Tammerfors och med att det röda väldet i Helsingfors har fallit. I de här böckerna är frihetens timme inne, och inte med ett ord berättas det om vad som hände därefter. Vad händer då unga män, uppfyllda av både testosteron och sin egen färska upplevelse av förödmjukelse, friges och upptäcker att den tidigare motståndaren, som förfallit till grymma handlingar, nu är helt och hållet besegrad?

I sitt segerrus bildade de vita bataljoner, om vilka man i samtida brev sade att de kom för att skipa rätt. Men i verkligheten var de bestraffningsbataljoner, bildade för att döda, åtminstone till en början. Att gå med i dem eller inte - det var en knepig valsituation för många av den tidens borgar- och bondsöner. Man kan bara föreställa sig den peer pressure, det kamrattryck, de unga männen upplevde i den här situationen.

Just dessa män försökte jag skildra i Där vi en gång gått, de som var uppfyllda av hämndbegär och de som inte var det men ändå deltog, för att de kände att de inte kunde annat. Eller åtminstone inte vågade göra på något annat sätt. Sedan bar de med sig skulden under resten av sina liv, och en del av dem, förmodligen ganska många, orkade till slut inte bära den. Under det påföljande decenniet förekom i Finland många självmord bland unga män som varit involverade $\mathrm{i}$ inbördeskrigets efterspel. Självmord förekom bland de förödmjukade och förbittrade röda, men också mycket frekvent på den segrande vita sidan. Man började bygga upp landet, för det måste man, i en situation där förlorarna var tvungna att kväsa sin bitterhet och segrarna sina känslor av skuld.

Det här var det viktigaste nya motivet jag ville foga till vårt sätt att betrakta inbördeskriget. I Där vi en gång gått försökte jag beskriva 
de skuldkänslor som förmodligen var vanliga på i920-talet, och som fortfarande förekom på I930-talet bland känsligare personer på den segrande vita sidan. Det onda samvetet som vaknar, och sedan plågar en. Frågorna som börjar pressa på: Vad var det vi gjorde? Hur kunde vi hämnas så besinningslöst?

Var och en besvarade sedan dessa frågor på sitt eget sätt, var och en var ensam med sitt eget samvete. Någon bröt ihop, någon annan teg som muren och gick envist vidare medan han försökte glömma det som hänt. Man tänkte sig att tiden läkte alla sår. Det var samma metod som många finländska män skulle använda drygt 25 år senare, efter all ond bråd död och alla svåra umbäranden under vinterkriget, fortsättningskriget och Lapplandskriget.

Vittnesmål om det dåliga samvetet och tvånget att tiga efter inbördeskriget finner man främst i privata brev. Det är beskrivande att det är just i privat korrespondens som tvånget att tiga avslöjas, inte i massmedier eller offentliga dokument. Utåt var man tvungen att upprätthålla fasaden och bygga upp landet. Så här skriver John Gardberg år 1965 i ett brev som finns citerat i boken Över branten. Bröder i krig I9I7-I9I8: "Det är inte vår sak att skriva vårt eget äreminne - vi ha rätt att försvara oss mot feltolkningar av våra avsikter, men också i fråga om sådant måste vi med ett kyligt omdöme avgöra när vi ha större orsak att tiga än att tala eller tvärtom.”

I Där vi en gång gått skildrar jag de vita bestraffningsbataljonernas verksamhet; jag gör det med fiktionens medel men läste flera historiska verk under skrivandet och försökte efter bästa förmåga tillämpa den plausibilitetsteori jag beskrev i början. Västnyländska bataljonen var en sådan straffenhet. Den höll till i lantmannaskolans byggnader på Västankvarn. I Västnyländska bataljonen, i rollen som krigsdomare, verkade jägaren Erik Grotenfelt, som även hade deltagit i strider i Tyskland. Grotenfelt var också poet och författare. Jag skildrar honom inte i Där vi en gång gått, utan berättar i stället om unga män som stod lägre i rang än han. Jag berättar om dem som gav sig ut i byarna för att hämta de röda, och som förde dem för att dömas och bestraffas.

2. Annvi Gardberg, Anders Gardberg \& Aapo Roselius, Över branten. Bröder i krig I9I7-I9I8, Mariehamn: PQR 20I8, s. 262. 
Ännu i maj 1918 hade de ibland inte tålamod att låta de röda få en dom, utan sköt dem på fläcken eller under färden.

Det saknas detaljerade uppgifter om verksamheten i Västnyländska bataljonen. Alla dokument förstördes redan i ett tidigt skede. Det enda dokumentet som finns kvar är krigsdomaren Erik Grotenfelts oförsiktiga brev till sin hustru. Det är ett privat brev där han beskriver hur han efter arkebuseringarna delade ut nådaskott i pannan eller nacken till de arkebuserade, och hur en del av de som skulle dödas bad om nåd medan andra var trotsiga till slutet, och hur han föraktade dem alla. Grotenfelt begick självmord bara ett år efter inbördeskriget. Orsaken till självmordet vet man inte med säkerhet.

Jag har följt Västnyländska bataljonens fotspår också i min senaste roman Den svavelgula bimlen (2017). Handlingen i romanen utspelar sig huvudsakligen under en tid som ligger mycket närmare vår, men också där löper trådarna bakåt ända till inbördeskriget.

I centrum står här Poa eller Per-Olof, patriark i den förmögna och inflytelserika släkten Rabell. Han har ingått i en straffbataljon våren 19I8, bara 15 år gammal. I romanen hänvisas till en arkebusering av röda, och jag har skrivit boken så att man inte vet om Ramslandet, där avrättningen sker, finns i västra eller östra Nyland. Men i skildringen har jag tagit intryck av ett känt fotografi från just Västankvarn. På bilden förs en grupp röda fångar för att arkebuseras och bland männen, som är klädda i smutsiga och trasiga paltor, går också en helt vitklädd kvinna fullt utstyrd i schal och huckle. På följande bild ligger den vitklädda kvinnan död bland de avlidna männen, ännu ett lik i ett vårligt åkerlandskap. Hon är en av de kvinnor som arkebuserades av Västnyländska bataljonen och hennes namn var med stor sannolikhet Hilma Heino eller Tekla Åhl. ${ }^{3}$

$* * *$

3. Jag vill i det här sammanhanget nämna att jag under arbetet med romanen Där vi en gång gått hade enorm hjälp av det grundarbete som några lokalhistoriker $\mathrm{i}$ nordvästra Nyland hade gjort, samt av verk de gett ut. Jag har för vana att i mina romaner inkludera ett efterord där jag tackar dem som antingen personligen eller via sitt arbete har hjälpt mig. Den gången glömde jag att nämna några viktiga lokalhistoriker, exempelvis Esa Koskinen som skrivit om Lojo samt Tauno Tukkinen som sedermera blivit mycket känd för sina många verk om inbördeskriget. 
Jag vill ge en liten sammanfattning av hur inbördeskriget skildrades i den samtida finlandssvenska litteraturen. Strax efter krigsslutet ville många kända poeter rättfärdiga kriget. Också i Erik Grotenfelts författarskap finner man spår av kriget, men han hann inte ge ut något nytt före sitt självmord. Däremot utkom diktsamlingar av poeter som Bertel Gripenberg och Örnulf Tigerstedt (som båda var influerade av högerextrema tankegångar) och av den finlandssvenska publikens favorit Jarl Hemmer, som dyrkades av många kvinnliga läsare. Innehållet i dessa samlingar var enligt dagens måttstock rena rama hatpratet. Lästa med dagens ögon är särskilt krigsdikterna i Gripenbergs Under fanan (I9I8) extremt kväljande i sättet på vilket de avklär krigets förlorande part all mänsklighet.

Till och med Runar Schildt, min ständiga favorit och min ungdoms stora förebild som novellist, sviker. Visserligen bara en gång, men ändå. I novellen "Aapo" (IgIg) förfaller han till att teckna en schablon av den trumpna, hämndlystna och upproriska finskspråkiga drängen. "Aapo" utgavs strax efter inbördeskriget; i de andra noveller där Schildt skriver om denna tid är han betydligt mera ambivalent och nyanserad. Till exempel i skildringen av en mors oro för sin son i novellen "Hemkomsten" (I919), eller i novellen "Köttkvarnen"(r919) vars handling Nyrki Tapiovaara flyttade från det känsliga och laddade I9I8 till ofärdsåren I904-05 i sin film Varastettu kuolema (1938, sv. Den stulna döden). Och så har vi förstås den berömda repliken, fälld av den skrivkrampsdrabbade författaren Jacob Casimir i ett av Schildts sista stora arbeten - novellen "Häxskogen" (1920):"För oss finns ingen plats i livets vita och röda garden."

En annan författare som uppenbarligen ångrade de dikter han skrivit direkt efter inbördeskriget var den populära Jarl Hemmer. Under senare delen av 1920-talet arbetade han på ett drama som hette Gehenna och ljusstrålarna, som Svenska Teatern då valde att inte uppföra. Hemmer omskrev dramat i romanform, under titeln En man och hans samvete (193I). Hemmer skildrar en präst i fånglägret på Sveaborg, vars jakobskamp sträcker sig över hela romanen, och hur denne sommaren

4. Runar Schildt, Häxskogen och andra noveller, Helsingfors: Holger Schildts förlagsaktiebolag I920, s. 270, elektronisk utgåva, Litteraturbanken, https://litteraturbanken.se/forfattare/SchildtR/titlar/Haxskogen/sida/3/etext (hämtad I6/5 20I9). 
I9I8 låter sig avrättas i stället för en röd fånge för att på så sätt erkänna sin skuld och sona sin synd. Denna drabbande och respektingivande skildring, som för en modern läsare dock framstår som uppskruvat patetisk, utkom 193I och vann en stor nordisk romanpristävling.

Det fanns förstås också arbetarlitteratur och borgerlig litteratur som sympatiserade med arbetarklassens ideologiska strävanden. Gunnar Björling, i eftervärldens ögon vår största eller åtminstone mest nydanande manliga poet, är undflyende som politisk gestalt. Men under ofärdsåren var han en aktivist som kämpade mot förryskningen, och under inbördeskriget sympatiserade han med de vita. Man har rentav hävdat att han mot slutet av kriget skulle ha varit ombord på den båt ur vilken den röda författaren Algot Untola (känd också under olika pseudonymer, exempelvis Maiju Lassila) knuffades i havet. Eller hoppade, i ett försök att fly. Untola sköts sedan, och man har alltså hävdat att Björling skulle ha sett Untola dö. Den här uppgiften har inte kunnat bekräftas. ${ }^{5}$

En annan viktig modernistpoet, Elmer Diktonius, hade en stark vänsterideologi. Det kommer tydligast till uttryck i hans ungdomsdikter som hyllar maskinåldern och fabrikerna samt även den kollektiva styrkan och revolutionära potentialen hos fabriksarbetarna. Dikternas sociala hetta avtar när Diktonius uppnår medelåldern. Där kvinnliga författare som Sigrid Backman och Jakobstadsbon Anna Bondestam, eller till exempel Elvi Sinervo i den finskspråkiga litteraturen, känsligt skildrar bildningshungern och strävan efter värdighet i hårda förhållanden bland den arbetarbefolkning som utför slitsamt skiftarbete mot usel lön, så är de röda arbetarna i Diktonius novellsamling Medborgare i republiken Finland (1935) och kortromanen Janne Kubik (I932) i anmärkningsvärt hög grad opportunister, människor med en tvivelaktig moral.

Den nyssnämnda helsingforsaren Sigrid Backman är i dag en nästan bortglömd författare. I början av r920-talet utgav hon två romaner som fokuserar på olika skeden i arbetarbefolkningens och de rödas tillvaro i inbördeskrigets efterdyningar. Den ena romanen,

5. Mer om denna händelse står att läsa i Fredrik Hertzberg, "Mitt språk är ej i orden". Gunnar Björlings liv och verk, Skrifter utgivna av Svenska litteratursällskapet i Finland 820, Helsingfors: SLS \& Stockholm: Appell Förlag 2018, s. I49-I50, http:// urn.fi/URN:NBN:fi:sls-978-95I-583-465-2 (hämtad 22/5 2019). 
Ålandsjungfrun (1919), utspelar sig på landsbygden i den fiktiva byn Pigbacka medan handlingen i den andra romanen, Familjen Brinks öden (1922), är förlagd till Helsingfors. Familjen Brinks öden är en bra och balanserad roman som enligt min uppfattning skulle förtjäna statusen minor classic. Den andra nyssnämnda författaren, Anna Bondestam, fick under sin livstid mycket större uppskattning än Sigrid Backman och hon är även mera känd för eftervärlden. Den fina romanen Klyftan (1946) skildrar inbördeskrigets Jakobstad ur ett barnperspektiv. Fina är också många av de fackböcker där Bondestam utforskar den finlandssvenska arbetarrörelsens historia. Bondestam promoverades till hedersdoktor vid Helsingfors universitet och fick år 2008 även Pro Finlandia-medaljen; hon var en finlandssvensk arbetarförfattare som också fick uppskattning för det hon gjorde.

Via Elmer Diktonius, Sigrid Backman och Anna Bondestam har jag nu nått den punkt där jag vill betona hur felaktig fördomen om finlandssvenskarnas kompakta borgerlighet varit och är. Även den svenskspråkiga befolkningen i Finland var djupt kluven under inbördeskriget och efter det - det fanns finlandssvenskar också bland de röda, på alla nivåer. Det fanns ledande gestalter i den socialistiska rörelsen, såsom Edvard Gylling, och det fanns vanliga män i rödgardisternas led. Också senare har det varit så. K.H. Wiik och KarlAugust Fagerholm blev ledande gestalter inom socialdemokratin, och Fagerholm var en röst ifrån att bli Finlands president. Under de allra senaste decennierna har två svenskspråkiga Anderssonar lett Vänsterförbundet, Claes och Li.

I de av mina romaner som utspelar sig under första hälften av 1900-talet har jag försökt föra fram den svenskspråkiga vänstertraditionen $\mathrm{i}$ vårt land. Till exempel att det vid tiden för inbördeskriget, och ännu en tid efter det, fanns en levande och äkta svenskspråkig arbetarkultur i Helsingfors, med egna dansställen och samkväm. Denna kultur var språngbrädan för sångarbröderna Malmstén, Georg och Eugen, liksom för många andra. Helsingfors forna arbetarstadsdelar Berghäll och Vallgård, som i dag uppfattas som helt finskspråkiga eller åtminstone icke-svenskspråkiga, var i tiden mycket mer tvåspråkiga än vi föreställer oss nu. Så uppstod också den berömda gamla helsingforsslangen, "stadin slangi" - ur en villervalla av olika språk. Man talade finska och svenska om vartannat, och även ryska, och så utvecklades 
slangen. Och det här hände inte i de stadsdelar som beboddes av överklassen utan i arbetarbefolkningens, folkets kvarter.

Fotbollsspelaren och sjömannen Allu Kajander och hans far Enok i Där vi en gång gått tillhör den eftersatta gruppen av svenskspråkiga arbetare och socialister; de har sina rötter i Sibbo öster om staden. Matilda Wiik i Hägring 38 har däremot en komplicerad språklig bakgrund, så som människor alltid haft i Helsingfors. Matildas far är svenskspråkig arbetare, medan hennes mors flicknamn är Nikitin och moderns språk sannolikt ryska och finska.

Då jag skapade karaktären Matilda Wiik hade Tuulikki Pekkalainens verk Susinartut ja pikku immet ${ }^{6}$ (20II, sv. ung. Varghyndor och små jungfrur) och många andra fackböcker en stor betydelse. Sedermera har det kommit ut allt fler böcker som fördjupar sig i inbördeskrigets kvinnoöden och kvinnans ställning vid denna tid. Som ett exempel kan nämnas Tiina Lintunens Punaisten naisten tiet $^{7}$ (sv. ung. De röda kvinnornas vägar) som utkom 2017.

Många frågor kring inbördeskriget är sådana att jag grubblat på dem ända sedan jag började intressera mig för epoken - då var jag fortfarande mycket ung. Men så finns det andra frågor, sådana som gjort sig påminda först när åren gått och min kunskap och förståelse gradvis fördjupats. En sådan fråga, som blev särskilt smärtsam medan jag skrev Där vi en gång gått, är denna:

Hur mycket arrogans fanns det bland den svenskspråkiga överklassen i relation till just de finskspråkiga röda, särskilt på sådana orter där båda språkgrupperna var starkt närvarande? Och vilken betydelse hade denna klassmedvetenhet, känslan av överlägsenhet, i slutskedet av kriget? Den känslan hade de röda utmanat genom att göra uppror och ta unga vita överklassmän till fånga i början av kriget, och där finns en koppling till det behärskat kalla raseri som kännetecknade vinnarnas hämnd- och straffåtgärder under våren och sommaren I9I8. Dessa genomfördes först i form av arkebuseringar och sedan genom att förlorarna stängdes in i fångläger där förhållandena var så vidriga att tusentals och åter tusentals fångar dog.

6. Tuulikki Pekkalainen, Susinartut ja pikku immet: Sisällissodan tuntemattomat naiset, Helsinki: Tammi 201 .

7. Tiina Lintunen, Punaisten naisten tiet, Helsinki: Otava 2017. 
Jag vill betona att denna fråga fanns starkt i mitt medvetande redan för 15 år sedan. Och jag har talat om ämnet i november $2017 \mathrm{i}$ Björneborg och på Helsingfors arbetarinstitut (Helsingin työväenopisto) i februari 20r8, alltså redan innan frågan fick offentlighet tack vare professor Seppo Hentiläs bok Pitkät varjot ${ }^{8}$ (2018) och de talrika intervjuerna med honom vårvintern 20I8. Det medierna lyfte fram ur boken var - lite förenklat - att en finlandssvensk bördshögfärd skulle ha bidragit till de vitas grymhet efter krigsslutet.

Jag tror inte jag är den enda svenskspråkiga finländaren som brottats med den här frågan. Men ämnet är så komplicerat att det blir svårt att behandla. Det förflutnas handlingar och dåd måste ses i ljuset av den anda och de attityder som rådde vid den tiden.

Under åren före inbördeskriget, och under kriget och också efteråt, förekom det rasism, socialt förakt och renodlat hat i alla samhällsskikt, och föraktet och hatet riktade sig både uppifrån ner och nerifrån upp. Tidsandan var sådan. Och det gör det svårt att avläsa i hur hög grad en språkbunden eller rentav etnisk känsla av överlägsenhet kan ha ökat strängheten och grymheten $i$ I9I8 års gärningar. En annan sorts överlägsenhetskänsla, till exempel baserad på rikedom eller utbildning, kan ha spelat en lika viktig eller ännu viktigare roll. Och på samma sätt är det svårt att definiera alla de socialpsykologiska och psykologiska faktorer som göder den sämre lottades hat mot dem som har det bättre.

För att undvika missförstånd vill jag vara tydlig med var jag står. Jag betraktar alla överlägsenhetskänslor av de ovannämnda slagen som villfarelser. Varje förevändning som någon använder för att utmåla en människogrupp som förmer än någon annan - språk, etnisk bakgrund, kön, samhällsklass, utbildningsnivå etcetera - är felaktig och skev. Under mitt liv har jag upplevt både godhet och ondska, både smarthet (och det finns smarthet av väldigt många olika slag) och dumhet i alla samhällsklasser, i alla språkgrupper och i alla länder där jag rört mig. Jag tror inte på fållor, och inte på att folk eller människogrupper kan rangordnas hierarkiskt.

8. Seppo Hentilä, Pitkät varjot: muistamisen historia ja politiikka, Helsinki: Siltala 2018. 
Mitt svar på den tidigare ställda frågan har redan länge - långt innan professor Hentilä lyfte fram ämnet i offentligheten - varit att arrogans, nedlåtande attityder och rentav rastänkande har förekommit i den svenskspråkiga överklassen i Finland. Men till samma överklass hörde också Hjalmar Linder, som våren I9I8 skrev i Hufoudstadsbladet att dödandet måste få ett slut, liksom inspärrandet av människor i fångläger. Det vita Finland blev så rasande över Linders insändare att han i praktiken blev tvungen att fly landet; han dog bara några år senare i landsflykt i Nordafrika.

Och arrogansen var ju inte knuten till ett visst språk - svenskan - och det var inte heller rastänkandet, båda fanns också bland språkmajoriteten. Om vi till exempel föreställer oss Akademiska KarelenSällskapet på I920-talet, och den finskspråkiga elit som där började drömma om ett Stor-Finland, så tror jag vi kan vara tämligen säkra på att inte heller den miljön var fri från rastänkande.

Vi bör också minnas att vita och röda, oberoende av språk, odlade grymma schabloner och nidbilder av varandra redan flera år innan inbördeskriget bröt ut. När jag i januari 2018 öppnade en utställning om år I9I8 i Paasitorni (Helsingfors arbetarförenings byggnad) i Helsingfors, uttryckte jag det ungefär så här:

När vi gräver ner oss i våra andliga skyttegravar lyssnar vi inte längre på motparten och ser inte längre hen som en hel människa med goda och dåliga sidor. I stället odlar vi onda berättelser om motståndaren, sår skräck och förakt, målar upp nidbilder som vi sedan börjar tro på. Det är så här motståndaren görs till fiende. Det är den här vägen som leder till våld och krig.

Under vårvintern och våren I9I8, när de vitas seger började se allt mera sannolik ut, accelererade avhumaniseringen av de röda på både finska och svenska. Författaren Ilmari Kiantos ord om de röda kvinnorna som varghyndor som borde dödas är isande i sin omänsklighet. Även V.A. Koskenniemi och Eino Leino skrev uppviglingspoesi. Det fanns orter där behandlingen av de röda i krigets slutskede blev särskilt grym utan att någon svenskspråkig deltog: till exempel fånglägret i Hennala och den massavrättning av kvinnor som skedde där, eller 
det Jämsä som Jukka Rislakki skildrade i sitt verk Kauhun aika9 (sv. ung. Skräckens tid). Om det har varit svårt för finlandssvenskarna att möta och bearbeta inbördeskrigets verklighet, så har det varit det också för de finskspråkiga.

En viktig skillnad är att det svenskspråkiga Finland inte fick sin egen Väinö Linna i övergången mellan 1950- och 1960-talet. Visst var Linna viktig också för oss svenskspråkiga. Men kanske hade vi ändå behövt en egen romanförfattare som, i likhet med Linna, hade öppnat nya perspektiv med sin vidsynthet och förståelse.

Essäisten Johannes Salminen (I925-20I5) gjorde visserligen ett strålande arbete nästan på egen hand, öppnade modigt de variga såren $i$ vår historia mitt under 1960-talets samhälleliga omvälvningar. Men en essäist, hur briljant hen än är, når sällan en lika bred läsekrets som romanförfattaren som skriver realistisk epik. Och inte heller arbetarlitteraturen fick någonsin det utrymme på finlandssvenskt håll som den fick på finska och även i Sverige.

Det har knappast heller saknat betydelse att Svenska folkpartiet, som bildades för att bli finlandssvenskarnas gemensamma parti, alltid varit borgerligt. På 1960- och 1970-talen var partiet visserligen mycket socialliberalt, men borgerligt även då. Vänsterpolitiken har, i ett finlandssvenskt perspektiv, alltid befunnit sig i marginalen. Men det finns en finlandssvensk vänsterpolitik och en finlandssvensk arbetarkultur. Min avsikt har varit att lyfta fram dem, både i mina romaner och i den här essän.

Dragsvik i Ekenäs, ett av de mest ökända fånglägren för röda, har fungerat som garnison för svenskspråkiga värnpliktiga sedan år 1946 . Jag vet med fullständig säkerhet att man inte berättat särdeles mycket för rekryterna eller andra om garnisonens dystra historia. Det dröjde ända till slutet av r980-talet innan den dåvarande, mycket humana ärkebiskopen John Vikström välsignade minnesmärket för de döda röda fångarna. På motsvarande sätt var skyltningen dålig till minnesmärket över avrättningarna i Västankvarn då jag för första gången besökte stället kring millennieskiftet. Det var mycket svårt att hitta fram och den senaste kransen med blommor som någon lagt ner vid

9. Jukka Rislakki, Kauhun aika: neljä väkivallan kuukautta Jämsässä I9I8, Helsinki: Ajatus 2007 (förnyad och kompletterad utgåva av Rislakkis bok utgiven 1995). 
minnesmärket hade bleknat så att det inte längre gick att urskilja namnet på den person eller förening som lagt ner blommorna.

I dag finns tydlig skyltning vid Stamväg $5^{\mathrm{I}}$ till minnesmärket $\mathrm{i}$ Västankvarn. Det utkommer, också på svenska, allt fler historiska verk som ger nya perspektiv på händelserna I9I8 och fördjupar vår kunskap om året.Jag nämner här bara läraren och historikern Sture Lindholm; de böcker han skrivit om inbördeskrigets historia i västra Nyland har varit viktiga vägvisare framåt. Tigandet och vägran att acceptera vad som verkligen hände år I9I8, var länge ett problem för finländare, oberoende av språk. Så här sade Väinö Linna, i ett tv-program som A.B. Rundradion (nuvarande Yle) gjorde redan i966:

Jag tror att Finlands folk är moget att höra sanningen om sig själva och sitt förflutna [...]. Nationen, såväl som individen, mognar bara genom att möta verkligheten. Men om den ständigt behandlas som man behandlar en minderårig, så förblir den också minderårig. ${ }^{10}$

De senaste decennierna har jag ändå upplevt som ganska hoppingivande. De allra senaste åren har förstås bjudit på en backlash i form av mer högernationalism och främlingsfientlighet, och sannfinländarnas stora popularitet avslöjar också att spänningarna mellan språkgrupperna - svenskt och finskt - lever kvar. Men det finns också många tecken på att vi blivit klokare, inte minst när det gäller hanteringen av inbördeskriget och alla dess gruvliga händelser. Det finns fortfarande smärtpunkter och vi har inte nödvändigtvis samma uppfattning om vad som orsakade kriget, eller om de krigförande parternas motiv eller krigets gång. Men det behöver vi inte ha, inte så länge vi kan diskutera öppet och respektera varandra även då vi har skilda åsikter. Och jag hävdar att det är just det vi gjort de senaste åren; vi har öppnat upp saker och diskuterat. Man kan inte längre hävda att Finland tiger om år I918. Och bra så, för vi behöver både öppenhet och ett försonligt sinne för att förstå vad vi en gång gjorde mot varandra.

Io. Väinö Linna i tv-programmet Fånglägren 19I8, regisserat av Fredrik Hackman, redaktörer: Johannes Salminen, Nils-Börje Stormbom, K.J. Lång, A.B. Rundradion 22/2 I966, Svenska Yle, Arkivet https://svenska.yle.fi/artikel/2006/o9/o8/ fanglagren-I9I8 (hämtad 31/5 2019). Översättning av citatet: KW. 
Jag vill citera ytterligare några ord från 1966 . De är från samma tv-program där även Väinö Linna uttalade sig, men nu tillhör orden den redan nämnda Johannes Salminen: "Det finns en glömska, en omedvetenhet, som hjälper till att utlösa nya katastrofer. Därför att den får oss att upprepa gamla misstag." ${ }^{\prime 1}$

Föredraget som essän baserar sig på skrevs ursprungligen på finska.

\section{Översättning till svenska: \\ Anna Biström i samarbete med forfattaren}

Föredraget framfördes vid följande tillfällen:

8/II 20I7, Mikaelsgården, Björneborg.

II/2 20I8, Helsingfors arbetarinstitut (Helsingin työväenopisto)

I2/5 20I8, Sammatti, seminariet"Kenen Suomi? Sammatti I9I8" (sv. ung. Vems

Finland? Sammatti I9I8), arrangerat av Eeva Joenpelto-sällskapet.

Bearbetat och fördjupat under vintern och våren 20I8. Delar har också använts under öppningstalet vid I9I8-utställningen i Paasitorni (Helsingfors arbetarförenings byggnad), I8/I 20I8, och vid öppnandet av samma utställning på Skatuddens Casino II/9 2018.

II. Johannes Salminen i tv-programmet Fånglägren 19I8. 